\title{
Determinants of intention to use Islamic mobile banking: Evidence from millennial generation
}

\author{
Muamar Nur Kholid \\ Faculty of Economics, Universitas Islam Indonesia, Yogyakarta, Indonesia \\ *Corresponding author: muamar.nk@uii.ac.id
}

\section{Keywords:}

UTAUT, Perceived Risk, Perceived Financial Cost, Islamic Mobile Banking

\section{Article History}

Received : 18 April 2019

Accepted : 8 July 2019

Published: 30 July 2019

DOI:

10.20885/JEKI.vol5.iss2.art2

JEL:

C10, G21, Z12

\begin{abstract}
This research aims to identify factors affecting the intention of millennial customers to use the Islamic Mobile Banking (IMB). This research applies the Unified Theory of Acceptance and Use of Technology (UTAUT) with two additional variables namely perceived risk and perceived financial cost. The data of the research are from 142 respondents of the millennial generation. The research uses SmartPLS 2.0. The results reveal that the perceived risk and perceived financial cost significantly and negatively affect the intention to use the IMB. Meanwhile, the performance expectancy and effort expectancy significantly and positively affect the intention to use the IMB. The other two variables namely social influence and facilitating condition do not show any significant effect on the intention to use the IMB. Furthermore, this research discusses the impact of the results of the research, both in the theoretical and practical contexts.
\end{abstract}

\section{Introduction}

Indonesia is a country with great potential for Islamic finance, given that its population is predominantly Muslim. However, the development of Islamic finance, which mainly deals with the Islamic banking, seems to be stagnant and to competitively lose to Malaysia, considering that Islamic banking assets in Indonesia are only as much as five percent, which is still far behind Malaysia with twenty percent (Pitoko, 2018). In order to achieve a good level of growth, Islamic banks must be able to achieve a competitive advantage in order to attract more customers. One of the efforts that can be done to achieve this competitive advantage is to adopt information technology in providing services to the customers (Goh \& Sun, 2014). One of the innovations of technology that is currently emerging is mobile banking (Shaikh \& Karjaluoto, 2015). Mobile banking is an interface that allows customers to access the banking system through mobile phones anywhere and anytime (Raza, Shah, \& Ali, 2019). In Indonesia, mobile banking services are provided both by conventional and Islamic banks.

In order to achieve a competitive advantage, some Islamic banks in Indonesia have developed Islamic Mobile Banking (IMB). IMB is a service provided by Islamic banks which allows customers to conduct various financial transactions such as payments, purchases, money transfers, transaction notifications, or checking balances through mobile phones such as smartphones or tablets (Goh, Suki, \& Fam, 2014). One of the reasons why IMB is offered is that $83.44 \%$ of internet users in Indonesia access the internet through mobile phones (Asosiasi Penyelenggara Jasa Internet Indonesia, 2017). Several Islamic banks in Indonesia have been providing IMB, but some do not show any good success rate. For example, customers of Bank Syariah Mandiri mostly conduct transactions through the ATM and only 10-12\% of them conduct it through IMB (Fauzia, 2018). Another fact shows that banking services are the least services accessed by Internet users in Indonesia (Asosiasi Penyelenggara Jasa Internet Indonesia, 2017).

The success of mobile banking to achieve the competitive advantage can be gained when the banks are able to figure out the factors affecting the customer's decision to accept the provided mobile banking (Sun, Goh, Fam, \& Xue, 2012). Regarding this issue, this research aims to investigate the factors affecting Islamic bank customer's intention to use IMB. This research is important to be conducted because of several reasons. First, this research focuses on the mobile banking provided by Islamic banks in Indonesia because there is still limited research related to the use of mobile banking provided by Islamic banks in Indonesia. Moreover, Islam and Muslim's cultures have a big impact on people's daily life (Goh et al., 2014; Raza et al., 2019). Second, this research focuses on the respondent of Y generation or millennial generation.

The millennial generation is those who were born between 1982 - 2005 (Howell, Joad, Callahan, Servis, $\&$ Bonham, 2009). This generation is chosen because IMB users are mostly from this category and they are also prospective customers to use IMB (Nurcahya, 2018). The success of IMB on the millennial generation will 
definitely give benefits to Islamic banks, so the determinants of customer's intention to use IMB is important to be investigated. Moreover, the previous research related to IMB focuses on all categories of customers, not on a certain category. Some of them are the research conducted by Hanudin, Hamid, Lada, \& Anis, (2008) and Sun et al., (2012) which were conducted in Malaysia as well as Raza et al., (2019) which was conducted in Pakistan.

Third, this research applied Unified Theory of Acceptance and Use of Technology (UTAUT) developed by Venkatesh, Morris, Davis, \& Davis, (2003) to explain the acceptance of IMB by the millennial generation and the variables of Performance Expectancy (PE), Effort Expectancy (EE), Social Influence (SI), Facilitating Condition (FC). In this research, Perceived Risk (PR) is added because of the perception that says IMB service is believed to be riskier than the conventional one (Evon, 2016). Meanwhile, based on the previous research, Perceived Financial Cost (PFC) is added because it is importantly related to mobile banking (Luarn \& Lin, 2005). The use of these two variables is expected to support a better understanding related to the customer's intention to use IMB.

$\mathrm{PE}$ is the individual's perception of using the information technology or information system will help them to improve their working performance (Venkatesh et al., 2003). Dealing with IMB, PE is the customer's perception of using IMB which will improve their banking activities. The customers will use mobile banking service if they are sure that the system provides banking transaction services (Evon, 2016). In other words, they will use IMB if it gives positive impacts on their banking activities. PE is expected to be a significant factor which directly affects the customer's intention to use IMB (Luo, Li, Zhang, \& Shim, 2010). Meanwhile, EE is the individual's perception of the easiness of using or operating information technology (Venkatesh et al., 2003). The higher level of EE leads to the higher the customer's intention to use IMB. It is because they do not have to learn to operate IMB (Eze, Manyeki, \& Har, 2011). According to TAM, the perceived ease of use is the antecedent of the perceived usefulness (Davis, 1989). EE is also expected to give positive effects on PE (Venkatesh et al., 2003). Customers will have a high PE when they think that using IMB is easy and they do not need any extra effort (Zhou, Lu, \& Wang, 2010).

Another variable in UTAUT is SI, which is the individual's perception of how important friends, families, and other people in assessing the use of information technology (Venkatesh et al., 2003). Dealing with IMB, SI is the customer's perception of how the people around them assess whether they must use IMB or not. The opinions from the people around customer regarding the information technology are believed to have an effect on the individuals to use it (Hong, Thong, Moon, \& Tam, 2008; Oliveira, Faria, Thomas, \& Popovič, 2014). The last variable of UTAUT is FC, which is the individual's perception of technical supports provided to help them use the information technology anytime they need (Venkatesh et al., 2003). When customers use IMB, they will need the Internet connection, application, or mobile phone. The customers with good facilities will have a strong intention to use mobile banking (Baptista \& Oliveira, 2015).

Two variables considered important added to this research are PR and PFC. PR is the level of uncertainty over the results of the use of information technology or the uncertainty about the security of information technology used (Evon, 2016). If uncertainty in IMB is high, customers will be reluctant to use it in their financial transactions (Baek \& King, 2011). Meanwhile, PFC is the extent to which an individual believes that using mobile banking will require costs (Luarn \& Lin, 2005). The research of information technology acceptance highlights that motivation and economic outcomes often becomes the focus of these individuals (Luarn \& Lin, 2005). If customers have a perception of using IMB requires a lot of money or burdens their finances, they are reluctant to use it (Bhatiasevi, 2016).

\section{Research Method}

Figure 1 presents the research model related to the IMB acceptance based on UTAUT and the addition of two variables, PR and PFC.

The sampling location of this research was in Yogyakarta (Indonesia) as it has $63 \%$ of the Internet users, ranked in the second place after DKI Jakarta (Maulana, 2015). The sample of this study was the sub-group of a millennial generation because it has a wide range of age which indicates differences among them (Evon, 2016). University students were chosen as respondents in this research because of several reasons: they are in the millennial generation sub-group; this generation lives and grow in the era of technology; they are one of the mobile phone market targets; and they are considered to have a homogeneous demographic background (Evon, 2016; Roach, 2009).

The sample was chosen by convenience and purposive sampling techniques with the criteria of those who have used IMB. In the context of mobile banking, the sampling technique is in line with the research conducted by Evon, (2016); Raza et al., (2019); Zhou et al., (2010). There were 151 respondents participating in this research, but only 142 respondents filled the questionnaires completely. The details of sample demography can be viewed in Table 1. 


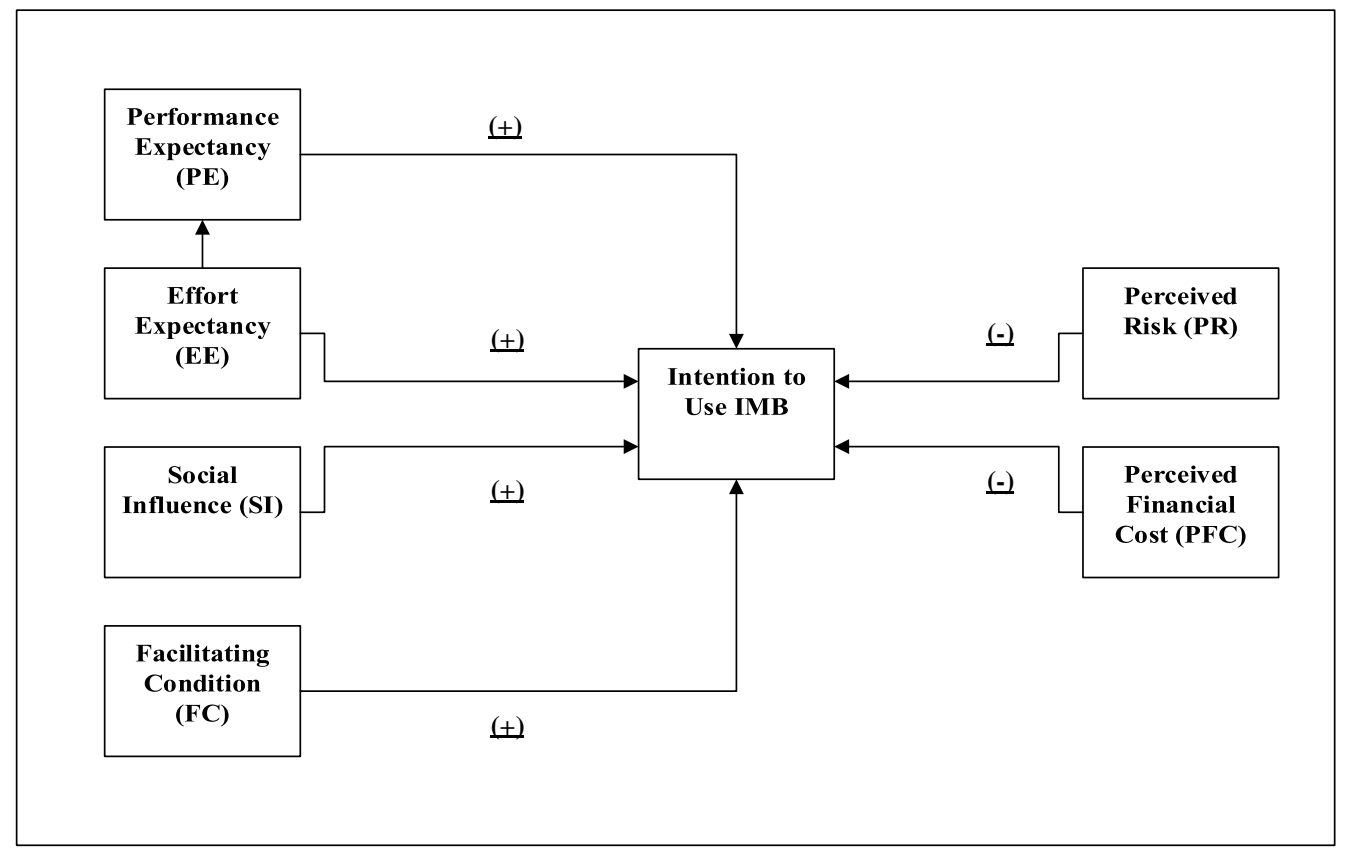

Figure 1: Research Model

Table 1. Respondent Demographic

\begin{tabular}{llll}
\hline & & Frequency & Percentage \\
\hline Gender & Male & 80 & $56,34 \%$ \\
Education Level & Female & 62 & $43,66 \%$ \\
& Diploma 3 & 11 & $7,75 \%$ \\
& Bachelor Degree & 124 & $87,32 \%$ \\
Age (years old) & Master & 7 & $4,93 \%$ \\
& 17 to 18 & 2 & $1,41 \%$ \\
& 18 to 19 & 16 & $11,27 \%$ \\
& 19 to 20 & 22 & $15,49 \%$ \\
& 20 to 21 & 70 & $49,30 \%$ \\
& 21 to 22 & 14 & $9,86 \%$ \\
& 22 to 23 & 4 & $2,82 \%$ \\
& 23 to 24 & 2 & $1,41 \%$ \\
& 24 to 25 & 8 & $5,63 \%$ \\
& 25 to 26 & 2 & $1,41 \%$ \\
& 26 to 27 & 2 & $1,41 \%$ \\
\hline
\end{tabular}

Table 1 shows that male respondents dominate the demography by 80 respondents. On education level, the students who attending undergraduate programs is dominating the demography by 124 respondents. From the age aspect, the majority of the respondents is between 20 to 21 years old, followed by 22 respondents in the range of 19 to 20 years old.

The questionnaires in this research applied the 6 likert scales, starting from 'strongly disagree' to 'strongly agree'. The items related to the UTAUT variables were adapted from Baptista \& Oliveira (2015), PR variable was adapted from Evon (2016) and PFC variable was adapted from Luarn \& Lin (2005) as described on table 2.

The reliability test was conducted by calculating the value of composite reliability (CR). If the CR value is more than 0.70, the study is reliable (Fornell dan Larcker 1981). In this research, the discriminant and convergent validity were applied to test the validity. The convergent validity evaluates that the items from the variables are really relevant to the variables themselves. It is gained if the value of the average variance extracted (AVE) for 
each variable is not less than 0.50 (Fornell dan Larcker 1981). The discriminant validity is revealed by having the correlation value between the same variables greater than the correlation value of the variable with the other variables (Fornell \& Larcker, 1981). Besides, it is also gained if the square root of AVE is more than the correlation value among variables (Fornell \& Larcker, 1981).

Table 2. Indicators on intention using Islamic Mobile Banking

\begin{tabular}{lll}
\hline \multicolumn{1}{c}{ Indicator } & & Item \\
\hline Performance & 1. & Usefulness in daily life \\
& 2. & Promote productivity \\
& 3. & Increase opportunities \\
& 4. & More efficient \\
\hline Effort & 1. & Fair and understandable \\
Expectancy & 2. & Easy to learn \\
& 3. & User friendly \\
& 4. & Easy to master \\
\hline Social Influence & 1. & Recommendation from people who influence user's behavior \\
& 2. & Important people around IMB user's \\
& 3. & IMB promote social status \\
\hline Facilitating & 1. & Basic knowledge \\
Conditions & 2. & Open resource service on IMB \\
& 3. & Compatible with other technologies \\
\hline Perceived Risk & 1. & Hesitation on services performance \\
\hline Perceived & 2. & Riskiness \\
\hline Financial Cost & 1. & Additional cost \\
\hline
\end{tabular}

The structural model in this research was applied to analyze the relationship of variables in the research model. The research model was tested by its model $\left(\mathrm{R}^{2}\right)$, path coefficient, and significance. Path coefficient $(\beta)$ and significance ( $\mathrm{p}$-value) were hypothetical tests which were formed in the model. The $\mathrm{R}^{2}$ test was applied to reveal the strength of the model in explaining the variables being researched. The measurement model and the structural model were analyzed using SmartPLS 2.0 software.

\section{Results and Discussion}

Appendix Table 3 indicates that the value of the loading factor on each item is more than 0.70 . It means that all construct items are valid. Dealing with the convergent validity, the value of AVE for all variables is more than 0.5. It means that the convergent validity is successful. The value of Cronbach Alpha and the composite reliability for all variables is more than 0.7 . It can be concluded that this study is reliable.

Regarding the discriminant validity, it is presented in Appendix Table 4 that the value of construct item correlation with the related construct is more than the correlation with the other constructs. It indicates that the discriminant validity is successful. Moreover, it is presented in Table 5 that the correlation matrix from the analyzed data shows that the value of the square root of AVE is more than the value of correlation among variables. It also indicates that it fits the discriminant validity criteria.

The result of the structural test shows that the four hypotheses are supported by the data. The complete result of the structural test can be depicted in Figure 2. PE has a significant positive effect $(\beta=0.1480)$ on the intention of customers to use IMB. This result is in line with previous research (Baptista \& Oliveira, 2015; Bhatiasevi, 2016; Evon, 2016; Raza et al., 2019). EE also has a significant positive effect $(\beta=0.2330)$ on the intention. This result is consistent with the previous research (Bhatiasevi, 2016; Evon, 2016; Raza et al., 2019). Meanwhile, the other variables in UTAUT, which are SI and FC, have no significant effect on the intention. The test result of SI, FC, and intention to use mobile banking is in line with the research conducted by Baptista $\&$ Oliveira (2015). The other test results show that PR $(\beta=-0.2854)$ and PFC $(\beta=-0.1754)$ have a significant yet negative effect on the customer's intention to use IMB. The result of this PR test is consistent with the previous research conducted by Evon (2016) and Luarn \& Lin (2005). 
The level of $\mathrm{R}$ square is $75.99 \%$ shows that the model related to the intention to use IMB is bold. This result is higher than that in Evon (2016) with the level of R square as 68.3\% and that in Baptista \& Oliveira, (2015) with the level of $R$ square as $69.1 \%$. Dealing with PE, it can be seen that $E E(\beta=0.5467)$ has a significant positive effect on PE. EE can explain $29.89 \%$ of the variance in PE. This result shows that the model related to PE is categorized as weak.

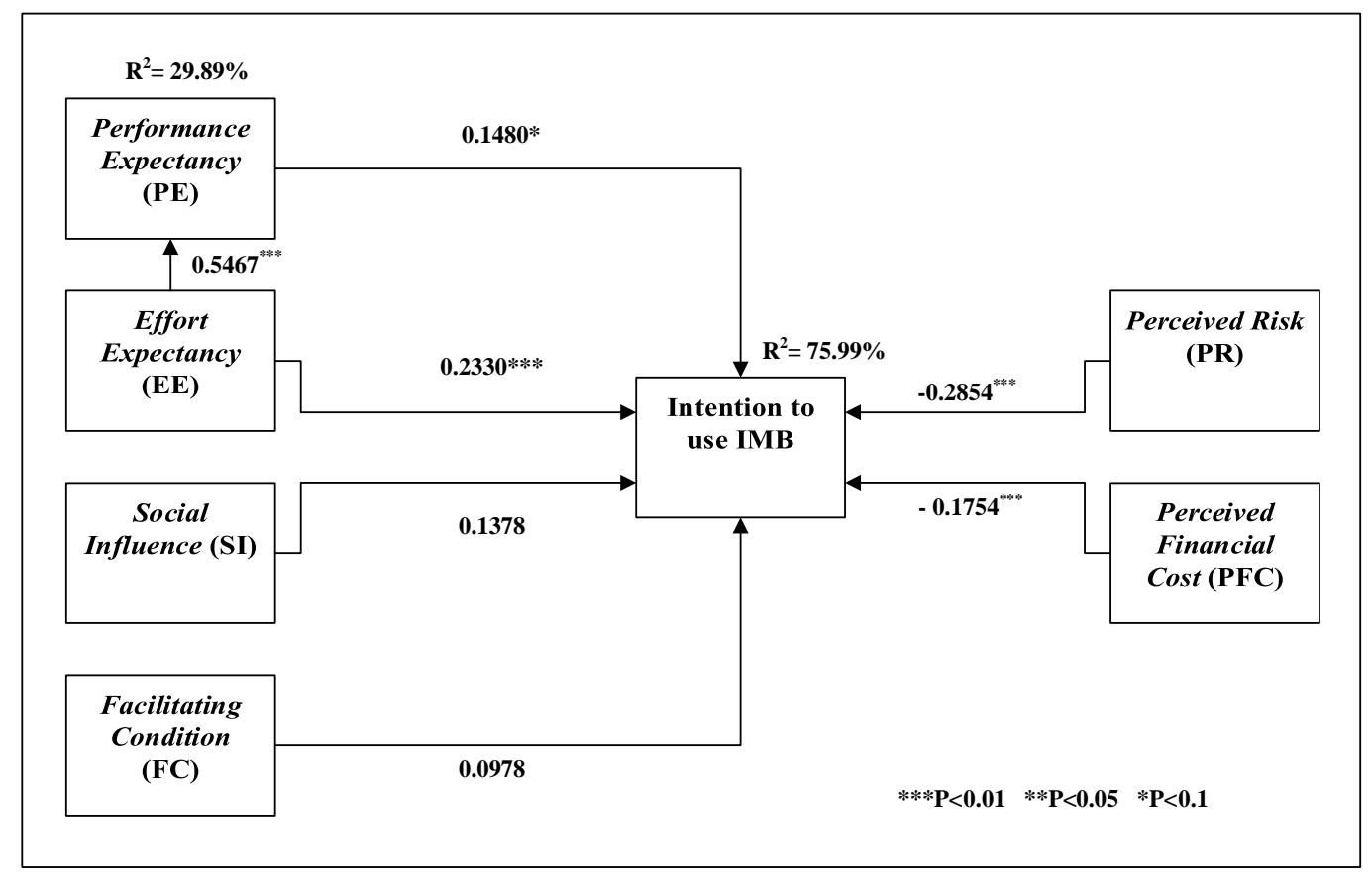

Figure 2. Result of Structural Model

The results of the test reveal that Perceived Risk is the variable which affects the intention of millennial customers to use Islamic mobile banking. The result indicates that millennial customers have an interest in the risks of doing transactions through Islamic mobile banking. They are averse to use Islamic mobile banking if they believe that it is highly risky and vice versa, they will not be reluctant if they believe that it has no significant risks. The role of Perceived Risk in determining this intention becomes logical, knowing that there are still some cases in Indonesia dealing with mobile banking security. This condition arises because the use of mobile banking dominates the financial service complaints, such as the down of mobile banking system, the error in the mobile banking debt, and the like (Hartomo, 2017). Regarding this issue, Islamic banks in Indonesia must be able to provide the best security system to guarantee the banking transaction security through Islamic mobile banking such as giving a warning about regular password changing to the customers for the security service. Besides, they also need to provide a 24-hour customer complaint services which is mainly related to the security issue. The customer complaint service is crucial as $24 \%$ of financial institutions state that the threats in 2016 are identified and reported by customers (Kaspersky, 2017).

The results of the research reveal that Effort Expectancy is the variable which affects the intention of millennial customers to use Islamic mobile banking and it has a significant positive effect on the intention. It means that they will use Islamic mobile banking if it is easy to use. The screen of the mobile phone which is relatively small and the input process using small pad become a challenge for all banks providing mobile banking service (Evon, 2016). Those two problems, the small screen and pad can affect customers to be reluctant to use Islamic mobile banking because it seems to be difficult to use. Moreover, Islamic banks in Indonesia are expected to provide Islamic mobile banking service in which the customers can proceed with the transactions fast and to give a clear manual. Through a good manual, customers will understand how to use Islamic mobile banking easily, so the intention to use it will increase. The results also show that effort expectancy has a significant effect onperformance expectancy. The millennial customers will have a high-performance expectancy if they believe that using Islamic mobile banking is easy and they do not need extra effort. It indicates that they believe that Islamic mobile banking will not improve their working performance if it is difficult to use. A complicated Islamic mobile banking, although with good system design and performance, will be avoided by the millennial customers (Evon, 2016). 
The results of the research reveal that performance expectancy has a significant positive effect on the intention of customers to use Islamic mobile banking. It indicates that when the millennial customers believe that Islamic mobile banking can improve their working performance, they will have a strong intention to use it. Regarding this matter, Islamic banks need to develop the Islamic mobile banking which can accommodate some types of transaction that can be done through it. The more services accommodated by Islamic mobile banking, the better the customers' performance. Moreover, Islamic banks also need to keep providing information related to convenience, advantages, and benefits of using Islamic mobile banking, so the customers believe that using Islamic mobile banking will benefit them.

The other variable affecting the customers to use Islamic mobile banking is Perceived Financial Cost. In line with Perceived Risk, Perceived Financial Cost has a significant negative effect on the intention of customers to use Islamic mobile banking. It indicates that the financial problem can be a burden for the millennial customers to use Islamic mobile banking. Regarding the respondents who are millennial customers, it becomes logical knowing that they are mostly students, not employees, and the financial problem is their focus. This result makes the mobile banking service providers need to decrease the financial perception by doing a pricing strategy or making creative advertisements (Luarn \& Lin, 2005).

Two other variables analyzed in this research are Social influence and facilitating condition. These two variables do not show any significant effect on the intention of millennial customers to use Islamic mobile banking. This result shows that the factor of people around the customer will not affect their intention to use Islamic mobile banking or not. It happens because Islamic mobile banking is related to financial matters which is confidential and sensitive, so the people around are not needed in order to keep the financial transactions confidential and protected (Oliveira et al., 2014; Raza et al., 2019).

\section{Conclusion}

This research is investigating the factors affecting the intention of millennial customers to use Islamic mobile banking. This research applied UTAUT with two additional variables namely Perceived risk and Perceived financial cost. The results of the research reveal that Performance Expectancy and Effort Expectancy variables in UTAUT have a significant positive effect on the customer to use Islamic mobile banking. Meanwhile, Social Influence and Facilitating Condition variables have no significant effect on it. Based on the tests of the two additional variables, which are Perceived Risk and Perceived Financial Cost, it is revealed that those variables have a significant negative effect on the intention of customer to use Islamic mobile banking. The results of this research show a strong model with the $\mathrm{R}$ square level as much as $75.99 \%$.

According to the results, the practical implication suggests Islamic banks to be able to guarantee the security of customer's transactions and to be able to assure the millennial customers that Islamic mobile banking has only low risks. In other words, it is safe to use Islamic mobile banking. Moreover, Islamic banks need to design a user-friendly Islamic mobile banking, so the millennial customers believe that using Islamic mobile banking is easy and they do not need any extra effort. Additionally, Islamic banks also need to vary the types of transaction which can be done through Islamic mobile banking, so the customers feel that it really gives benefits. Lastly, the millennial customers concern with the financial matter. It can affect their intention to use Islamic mobile banking, so Islamic banks need to create pricing strategies which can attract millennial customers.

Even though this research is able to explain the intention to use Islamic mobile banking, there are still some limitations which are expected to be completed by future research. First, this research explains the intention to use Islamic mobile banking using UTAUT and two additional variables namely Perceived Risk and Perceived Financial Cost. Future research can explore the intention to use Islamic mobile banking using other theories and other variables such as trust, habit, and the like. The important role of Perceived Risk in this research makes future research investigate the variables affecting Perceived Risk and the intention to use Islamic mobile banking more deeply. Second, this research is limited to investigate the factors affecting the intention to use Islamic mobile banking. The future research needs to test more than this, might be into the actual usage.

\section{Reference}

Asosiasi Penyelenggara Jasa Internet Indonesia. (2017). Penetrasi dan perilaku pengguna internet Indonesia, Survei 2017. Asosiasi Penyelenggara Jasa Internet Indonesia.

Baek, T. H., \& King, K. W. (2011). Exploring the consequences of brand credibility in services. Journal of Services Marketing, 25(4), 260-272. https://doi.org/10.1108/08876041111143096

Baptista, G., \& Oliveira, T. (2015). Understanding mobile banking: The unified theory of acceptance and use of technology combined with cultural moderators. Computers in Human Behavior, 50, 418-430. https://doi.org/10.1016/j.chb.2015.04.024 
Bhatiasevi, V. (2016). An extended UTAUT model to explain the adoption of mobile banking. Information Development, 32(4), 799-814. https://doi.org/10.1177/0266666915570764

Davis, F. (1989). Perceived Usefulness, Perceived East of Use, and User Acceptance of Information Technology. MIS Quarterly, 13(3), 319-340. https://doi.org/10.1016/S0305-0483(98)00028-0

Evon, T. J. L. L. (2016). Behavioural intention to adopt mobile banking among the millennial generation. Young Consumers, 17, 0-5. https://doi.org/http://dx.doi.org/10.1108/YC-07-2015-00537

Eze, U. C., Manyeki, J. K., \& Har, L. C. (2011). Factors Affecting Internet Banking Adoption among Young Adults : Evidence from Malaysia. International Conference on Social Science and Humanity, 5, 377381.

Fauzia, M. (2018). Kontribusi E-Channel Mandiri Syariah Capai Rp 170 Miliar. Retrieved April 10, 2019, from https://ekonomi.kompas.com/read/2018/11/26/194900626/kontribusi-e-channel-mandiri-syariah-capairp-170-miliar

Fornell, C., \& Larcker, D. (1981). Evaluating structural equation models with unobservable variables and measurement error. Journal of Marketing Research, 18(1), 39-50. https://doi.org/10.2307/3151312

Goh, T. T., Suki, N. M., \& Fam, K. (2014). Exploring a consumption value model for Islamic mobile banking adoption. Journal of Islamic Marketing, 5(3), 344-365. https://doi.org/10.1108/JIMA-08-2013-0056

Goh, T. T., \& Sun, S. (2014). Exploring gender differences in Islamic mobile banking acceptance. Electronic Commerce Research, 14(4), 435-458. https://doi.org/10.1007/s10660-014-9150-7

Hanudin, A., Hamid, M. R. A., Lada, S., \& Anis, Z. (2008). The Adoption of Mobile Banking in Malaysia: The case of Bank Islam Malaysia (BIMB). International Journal of Business and Society, 9(2), 43-53.

Hartomo, G. (2017). 1.305 Pengaduan Keuangan di Februari, Kasus Mobile Banking Mendominasi. Retrieved April 15, 2019, from https://economy.okezone.com/read/2017/03/30/320/1654908/1-305-pengaduankeuangan-di-februari-kasus-mobile-banking-mendominasi

Hong, S. J., Thong, J. Y. L., Moon, J. Y., \& Tam, K. Y. (2008). Understanding the behavior of mobile data services consumers. Information Systems Frontiers, 10(4), 431-445. https://doi.org/10.1007/s10796-008-9096-1

Howell, L. P., Joad, J. P., Callahan, E., Servis, G., \& Bonham, A. C. (2009). Generational Forecasting in Academic Medicine: A Unique Method of Planning for Success in the Next Two Decades. Academic Medicine, 84(8), 985-993. https://doi.org/10.1097/ACM.0b013e3181acf408

Kaspersky. (2017). Things to do before the next big thing: How the financial industry reacts to cyberthreats. Retrieved April 15, 2019, from https://www.kaspersky.com/blog/how-the-financial-industry-reacts-tocyberthreats/6610/

Luarn, P., \& Lin, H. H. (2005). Toward an understanding of the behavioral intention to use mobile banking. Computers in Human Behavior, 21(6), 873-891. https://doi.org/10.1016/j.chb.2004.03.003

Luo, X., Li, H., Zhang, J., \& Shim, J. P. (2010). Examining multi-dimensional trust and multi-faceted risk in initial acceptance of emerging technologies: An empirical study of mobile banking services. Decision Support Systems, 49(2), 222-234. https://doi.org/10.1016/j.dss.2010.02.008

Maulana, A. (2015). Jumlah Pengguna Internet Indonesia Capai 88,1 Juta. Retrieved April 10, 2019, from https://www.liputan6.com/tekno/read/2197413/jumlah-pengguna-internet-indonesia-capai-881-juta

Nurcahya, I. A. H. (2018). Bank Syariah Bidik Nasabah Milenial. Retrieved April 10, 2019, from https://finansial.bisnis.com/read/20181217/90/870229/bank-syariah-bidik-nasabah-milenial

Oliveira, T., Faria, M., Thomas, M. A., \& Popovič, A. (2014). Extending the understanding of mobile banking adoption: When UTAUT meets TTF and ITM. International Journal of Information Management, 34(5), 689-703. https://doi.org/10.1016/j.ijinfomgt.2014.06.004

Pitoko, R. A. (2018). Bappenas: Perkembangan Ekonomi Syariah Indonesia Jalan di Tempat. Retrieved April 10, 2019, from https://ekonomi.kompas.com/read/2018/07/25/170000126/bappenas--perkembanganekonomi-syariah-indonesia-jalan-di-tempat

Raza, S. A., Shah, N., \& Ali, M. (2019). Acceptance of mobile banking in Islamic banks: evidence from modified UTAUT model. Journal of Islamic Marketing, 10(1), 357-376. https://doi.org/10.1108/JIMA-04-2017-0038 
Roach, G. (2009). Consumer perceptions of mobile phone marketing: A direct marketing innovation. Direct Marketing, 3(2), 124-138. https://doi.org/10.1108/17505930910964786

Shaikh, A. A., \& Karjaluoto, H. (2015). Mobile banking adoption: A literature review. Telematics and Informatics, 32(1), 129-142. https://doi.org/10.1016/j.tele.2014.05.003

Sun, S., Goh, T., Fam, K. S., \& Xue, Y. (2012). The influence of religion on Islamic mobile phone banking services adoption. Journal of Islamic Marketing, 3(1), 81-98. https://doi.org/10.1108/17590831211206617

Venkatesh, V., Morris, M. G., Davis, G. B., \& Davis, F. D. (2003). User Acceptance of Information Technology: Toward A Unified View. MIS Quarterly, 27(3), 425-478.

Zhou, T., Lu, Y., \& Wang, B. (2010). Integrating TTF and UTAUT to explain mobile banking user adoption. Computers in Human Behavior, 26(4), 760-767. https://doi.org/10.1016/j.chb.2010.01.013 


\section{APPENDICES}

Table 3. Result of Measurement Model

\begin{tabular}{|c|c|c|c|c|c|}
\hline Construct & Item & Loadings & Cronbach Alpa & Composite Reliability & AVE \\
\hline \multirow[t]{3}{*}{ Intention to Use IMB } & IN1 & 0.9274 & 0.9194 & 0.9489 & 0.8610 \\
\hline & IN2 & 0.9296 & & & \\
\hline & IN3 & 0.9267 & & & \\
\hline \multirow[t]{4}{*}{ Performance Expectancy } & PE1 & 0.8755 & 0.8302 & 0.8854 & 0.6595 \\
\hline & PE2 & 0.8186 & & & \\
\hline & PE3 & 0.7973 & & & \\
\hline & PE4 & 0.7521 & & & \\
\hline \multirow{4}{*}{ Effort Expectancy } & EE1 & 0.8902 & 0.9196 & 0.9433 & 0.8062 \\
\hline & EE2 & 0.8731 & & & \\
\hline & EE3 & 0.9397 & & & \\
\hline & EE4 & 0.8871 & & & \\
\hline \multirow[t]{4}{*}{ Facilitating Conditions } & FC1 & 0.8011 & 0.8537 & 0.9012 & 0.6953 \\
\hline & $\mathrm{FC} 2$ & 0.8705 & & & \\
\hline & FC3 & 0.8469 & & & \\
\hline & $\mathrm{FC} 4$ & 0.8149 & & & \\
\hline \multirow[t]{3}{*}{ Social Influence } & SI1 & 0.9056 & 0.8689 & 0.9196 & 0.7923 \\
\hline & SI2 & 0.9084 & & & \\
\hline & SI3 & 0.8553 & & & \\
\hline \multirow[t]{4}{*}{ Perceived Risk } & PR1 & 0.8697 & 0.8927 & 0.9256 & 0.7568 \\
\hline & PR2 & 0.8940 & & & \\
\hline & PR3 & 0.8384 & & & \\
\hline & PR4 & 0.8767 & & & \\
\hline \multirow[t]{2}{*}{ Perceived Financial Cost } & PFC1 & 0.9376 & 0.8409 & 0.9260 & 0.8623 \\
\hline & $\mathrm{PFC} 2$ & 0.9195 & 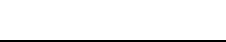 & 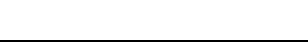 & \\
\hline
\end{tabular}

Table 4. Loading and Cross Loading

\begin{tabular}{crrrrrrr}
\hline & EE & FC & IN & PE & PFC & PR & SI \\
\hline EE1 & $\mathbf{0 . 8 9 0 2}$ & 0.6245 & 0.6528 & 0.5018 & -0.4347 & -0.5654 & 0.4386 \\
EE2 & $\mathbf{0 . 8 7 3 1}$ & 0.5105 & 0.5957 & 0.4373 & -0.4336 & -0.4810 & 0.4119 \\
EE3 & $\mathbf{0 . 9 3 9 7}$ & 0.6341 & 0.6363 & 0.5307 & -0.4427 & -0.5505 & 0.4051 \\
EE4 & $\mathbf{0 . 8 8 7 1}$ & 0.6200 & 0.6404 & 0.4890 & -0.4432 & -0.5809 & 0.4514 \\
FC1 & 0.4966 & $\mathbf{0 . 8 0 1 1}$ & 0.5522 & 0.4597 & -0.4904 & -0.5397 & 0.5016 \\
FC2 & 0.5646 & $\mathbf{0 . 8 7 0 5}$ & 0.6450 & 0.4904 & -0.4870 & -0.5530 & 0.4964 \\
FC3 & 0.6091 & $\mathbf{0 . 8 4 6 9}$ & 0.5872 & 0.5125 & -0.3875 & -0.5504 & 0.6047 \\
FC4 & 0.5547 & $\mathbf{0 . 8 1 4 9}$ & 0.5477 & 0.4277 & -0.4941 & -0.4762 & 0.4511 \\
IN1 & 0.6306 & 0.6691 & $\mathbf{0 . 9 2 7 4}$ & 0.5360 & -0.6511 & -0.7288 & 0.5980 \\
IN2 & 0.6912 & 0.6418 & $\mathbf{0 . 9 2 9 6}$ & 0.6929 & -0.5822 & -0.7843 & 0.6912 \\
IN3 & 0.6338 & 0.6414 & $\mathbf{0 . 9 2 6 7}$ & 0.6034 & -0.5912 & -0.6564 & 0.5508 \\
PE1 & 0.5059 & 0.5224 & 0.5843 & $\mathbf{0 . 8 7 5 5}$ & -0.3360 & -0.5103 & 0.5377 \\
PE2 & 0.2998 & 0.3809 & 0.4551 & $\mathbf{0 . 8 1 8 6}$ & -0.1952 & -0.4053 & 0.5165 \\
PE3 & 0.5368 & 0.4832 & 0.6282 & $\mathbf{0 . 7 9 7 3}$ & -0.4947 & -0.5464 & 0.4051 \\
PE4 & 0.3678 & 0.4271 & 0.4213 & $\mathbf{0 . 7 5 2 1}$ & -0.2603 & -0.4612 & 0.5697 \\
PFC1 & -0.5329 & -0.5608 & -0.6434 & -0.4005 & $\mathbf{0 . 9 3 7 6}$ & 0.6148 & -0.4950 \\
PFC2 & -0.3641 & -0.4668 & -0.5691 & -0.3750 & $\mathbf{0 . 9 1 9 5}$ & 0.5991 & -0.3445 \\
PR1 & -0.5570 & -0.5116 & -0.6653 & -0.5390 & 0.5569 & $\mathbf{0 . 8 6 9 7}$ & -0.4956 \\
\hline PR2 & -0.5938 & -0.5579 & -0.6983 & -0.6116 & 0.5946 & $\mathbf{0 . 8 9 4 0}$ & -0.4856 \\
PR3 & -0.4508 & -0.5975 & -0.7089 & -0.4568 & 0.6446 & $\mathbf{0 . 8 3 8 4}$ & -0.6851 \\
PR4 & -0.5132 & -0.5414 & -0.6426 & -0.4837 & 0.4677 & $\mathbf{0 . 8 7 6 7}$ & -0.5756 \\
SI1 & 0.4771 & 0.5462 & 0.6040 & 0.6125 & -0.4295 & -0.5868 & $\mathbf{0 . 9 0 5 6}$ \\
SI2 & 0.4696 & 0.5804 & 0.6283 & 0.6204 & -0.4114 & -0.5868 & $\mathbf{0 . 9 0 8 4}$ \\
SI3 & 0.3095 & 0.5150 & 0.5352 & 0.3856 & -0.3769 & -0.5498 & $\mathbf{0 . 8 5 5 3}$ \\
\hline N & &
\end{tabular}

Note: $\mathrm{EE}=$ Effort Expectancy; FC $=$ Facilitating Condition; IN = Intention/Niat; PE $=$ Perceived Expectancy; PR =

Perceived Risk; SI = Social Influence. 
Table 5. Correlation Matrix

\begin{tabular}{cccccccc}
\hline & EE & FC & IN & PE & PFC & PR & SI \\
\hline EE & $\mathbf{0 . 8 9 7 8}$ & & & & & & \\
FC & 0.6674 & $\mathbf{0 . 8 3 3 8}$ & & & & & \\
IN & 0.7038 & 0.7012 & $\mathbf{0 . 9 2 7 9}$ & & & & \\
PE & 0.5467 & 0.5675 & 0.6605 & $\mathbf{0 . 8 1 2}$ & & & \\
PFC & -0.4883 & -0.5561 & -0.6550 & -0.4182 & $\mathbf{0 . 9 2 8 6}$ & & \\
PR & -0.6077 & -0.6360 & -0.7819 & -0.6017 & 0.6538 & $\mathbf{0 . 8 6 9 9}$ & \\
SI & 0.4753 & 0.6158 & 0.6639 & 0.6132 & -0.4567 & -0.6458 & $\mathbf{0 . 8 9 0 1 1}$ \\
\hline
\end{tabular}

Note $: \mathrm{EE}=$ Effort Expectancy; FC $=$ Facilitating Condition; $\mathrm{IN}=$ Intention/Niat; PE $=$ Perceived Expectancy; PR = Perceived Risk; SI = Social Influence. 